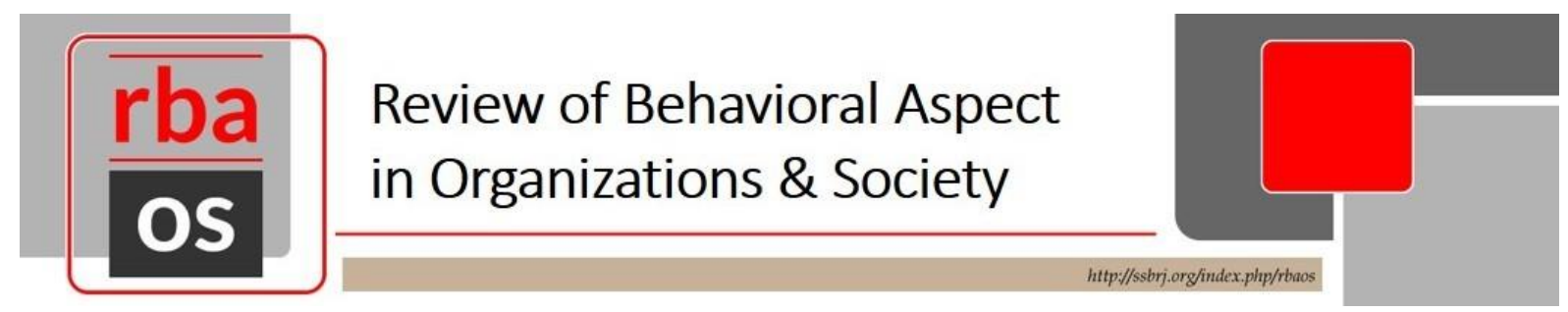

\title{
IMPACT OF JOB SATISFACTION ON JOB PERFORMANCE
}

\author{
Firman Alamsyah Ario Buntaran, Universitas Mercu Buana, Indonesia \\ Dicky Andika, Universitas Mercu Buana, Indonesia \\ Vita Yuli Alfiyana, Universitas Mercu Buana, Indonesia
}

\begin{abstract}
Basically, performance is something that is individual because each employee has a different level of ability to do their jobs. Performance depends on the combination of ability, effort, and opportunity obtained. Employee performance is capital for companies to survive and develop in responding to business and business competition today, advanced and developing companies are very dependent on reliable human resources so that the output is high performance on employee performance which will later affect the company's performance. However, it is not easy to maintain and improve employee performance. There are many factors that can affect performance. Many employee turnovers occur due to a lack of satisfaction with work. Employee performance is very dependent on the value of employee satisfaction in the workplace. The fulfillment of employee rights greatly affects the performance of the organization. So, in this study the focus of the study would like to see the extent of the influence of job satisfaction on employee performance in a national company engaged in oil palm plantations. The results showed that there was an effective contribution from the influence of employee satisfaction on employee performance. The research data was taken from 55 employees engaged in oil palm plantations in an office in the city of Jakarta. Keywords: job performance, job satisfaction
\end{abstract}




\section{Introduction}

The performance of employees is affected by numerous factors at workplace. It is defined as the way to perform the job tasks according to the prescribed job description. Performance is the art to complete the task within the defined boundaries. There are lots of factors that affect the performance of employees. The main theme of the study revolves around those variables. The problem statement is about factors affecting the performance of employees at workplace in the scenario of Pakistan. This study will focus on the banking sector to know about their performance and factors affecting them. The variables that are determined to affect the performance at the workplace include manager's attitude, organizational culture, personal problems, and job content, and financial rewards. These variables are described in different studies that affect the performance of employees at the workplace. This study will find out the impact of manager's attitude, organizational culture, personal problems, and job content, and financial rewards on job performance.

It will also highlight how these variables affect the performance, either positive or negative. Although the positive effect has been seen through the literature review, but this study will determine it again. The aim of the present study is to find out the relationship between independent variables and the dependent variable. The dependent variable is performance of employees. This study is quantitative, and data will be collected by questionnaire by 55 employees from oil palm plantations. For analysis, this study will use SPSS software by the application of regression analysis. The results will be drawn based on the data collected and finding, and conclusion will be given employees' performance. Data was collected through a questionnaire. Data analysis is performed by using Univariate Statistics, Pearson Correlations, and regression analysis.

\section{Review of the Literature \\ Job Performance}

Campbell, McHenry, and Wise (1990). said that employee performance as employee behavior or actions that can be observed with organizational goals. The behavior referred to by Campbell is how employees can think, plan, and solve a problem in work (Landy and Conte, 2013). This definition explains that employee performance is an action or behavior carried out by employees in carrying out their duties in accordance with the knowledge of the work they have.

\section{Job Satisfaction}

According to Robbins (2003), job satisfaction is a general attitude towards one's work that shows the difference between the number of awards received by workers and the amount they believe should be received. Spector views job satisfaction as a feeling of liking or disliking the work shown with some attitudes including never being absent, arriving on time, having enthusiasm, and high motivation. According to Spector (1997) Job satisfaction is how employees feel about jobs and different aspects of their work. This is related to the extent to which employees like (satisfaction) or do not like (not satisfied) with their work. As generally assessed, job satisfaction is an attitude variable. He also states that job satisfaction influences people's attitudes towards their work and various aspects of their work. Job satisfaction is influenced by personal and organizational factors, can cause emotional reactions that affect organizational commitment. 


\section{Job Factor performance}

There are a number of variables that can influence employee performance at work. That includes independent variable as employee's goal orientation; Employee performance in accordance with the objectives inviting employees, quality leader-members, and result satisfaction. There are a number of variables that can affect employee performance at work. That includes independent variable as an integrated goal of employees;

\section{Theories of Job Performance}

In the modern era, organizations are faced with many dynamic challenges that exist in the global business environment. Among the challenges of business organizations are related to the question of how to ensure task performance can continue to be maintained by ensuring employee satisfaction related to the constantly changing and evolving environment so that the organization can achieve what the goal is and still exist in competition. The study of the relationship between job satisfaction and work performance is one of the most interesting research traditions on industrial-organizational psychology.To improve good performance, businesses must meet the needs of their employees by providing good working conditions.

Dizgah, Chegini, Bisokhan (2012) argues that the most vital problem in a company is task performance. Total assignments make more complete research on evaluating the total expectations of the entire sample organization of each person over a certain period of time. Job satisfaction is a complex variable and is influenced by situational factors and individual disposition characteristics (Sharma \& Ghosh, 2006). Job satisfaction can be understood with the concept of one-dimensional global job satisfaction or multi-aspect construction, which includes various aspects of job satisfaction that can vary independently.

Pushpakumari (2008) argued that employee attitude is important for management because they set goals workers in the organization. The general opinion is that satisfied workers are productive workers. A satisfied workforce will create a pleasant atmosphere in the organization performs well. The specific problem discussed in this study is to test job satisfaction with performance. The purpose of this study is to analyze the effect of job satisfaction on task performance on employees. Data was collected through self-administered survey questionnaires. The questionnaire was adopted from previously validated surveys. The target population of the plantation industry is operating in Kalimantan and Sumatra, Indonesia. Simple random sampling is used to collect data from 55 employees. The results show that there is a significant effect of job satisfaction on employee job performance. This study concludes with some assumptions that business organizations need to realize the importance of high job satisfaction to maximize employee performance levels. This paper can benefit the industrial especially providing information related to how to maximize aspects of human resources. Therefore, it is very important for organizations to focus and improve employee welfare so that employees will work hard so that what becomes an organizational goal can be achieved. Based on the above theories and definitions review, the following framework has been formulated to depict the relationship between the dependent and independent variables.

Cummings (1970) identified that there are three main perspectives on the relationship between job satisfaction and employee performance. Satisfaction causes employee performance to increase or even decrease. This view is supported by various studies. Mirvis and Lawer (1977), in their study found a relationship between job satisfaction and performance. Teller banks, in the case of cash shortages, the argument put forward is the satisfied teller asks for references that come out of his job. Smith and Cranny (1968) 
conducted a study on the relationship between job satisfaction and employee performance. Satisfaction was related to the performance of relief efforts, commitment, and effort. At an electricity company, elated to increasing work productivity. The research conducted by Inuwa (2016) which proposes hypotheses that there is a positive and significant relationship between job satisfaction and the performance of non-academic university staff.

Khan, Nawaz, Aleem, and Hamed (2012) conducted a study related to the relationship between job satisfaction and employee performance. This study was conducted to study the determinants of job satisfaction and increase job satisfaction for employees in the autonomous financial institutions of the government of Pakistan. Research carried out to determine the determinants of job satisfaction and job satisfaction on finance in the autonomous field of the Pakistani Ministry of Health. It can be concluded from studies such as job satisfaction, promotion, safety and work, work, work, economy, relationships with colleagues, relations with superiors, and jobs that significantly increase the level of job satisfaction of Pakistan's health institutions.

Platis, Reklitis, and Zimeras (2015) also state that there is a close relationship between job satisfaction and performance as in other professional categories and this phenomenon discusses all over the world only, task performance, is a complex feature that depends except global job satisfaction, on many other unspecified needs. These conditions, operational conditions, social conditions, such as organizational commitment, work values.

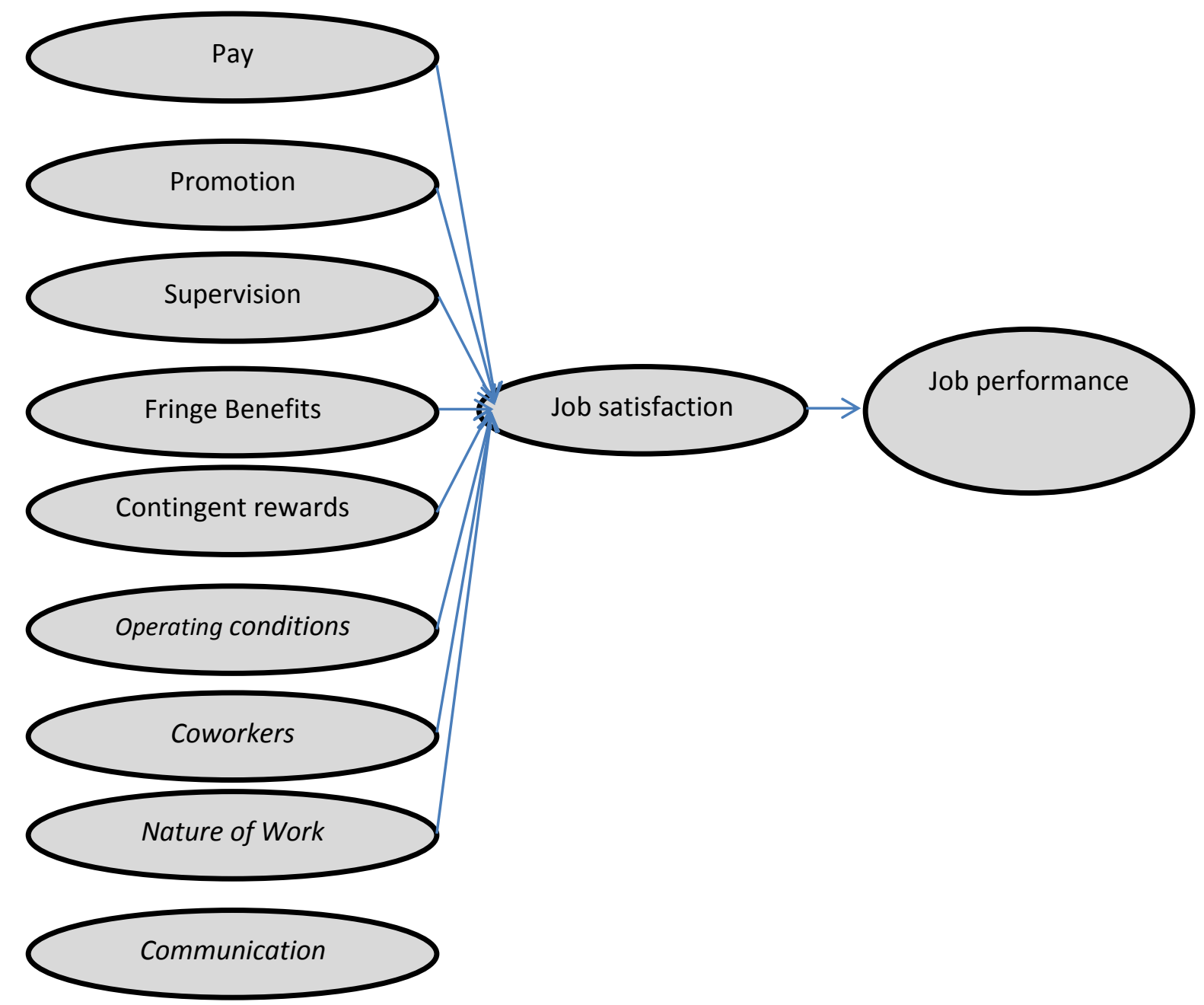

Figure 3-1 Theoretical Model 


\section{Research Methods}

The purpose of the study is to find whether the job satisfaction impacts on the employees' performance, which basically employee performance is the essential capital for companies to be able to compete in an increasingly competitive business environment at this time. Purposive sampling was used as the purpose is to get an insight into the factors that influence job satisfaction that influences employee's performance. Purposive sampling is used to select research samples on companies engaged in oil palm plantations. This is because these institutions have several numbers of employees especially in the oil palm plantations companies in which employee's turnover is high. A questionnaire was given to gather information from employees at offices engaged in oil palm plantations related to the purpose of the study, namely to see the effect of job satisfaction on employee performance.

The questionnaire consisted of 36 items of job satisfaction questionnaire and 18 items job performance. The responses were measured on the 4 points Likert scale ranging from 1-4.

\section{Reliability of the Questionnaire}

\section{Cronbach's Alpha}

\begin{tabular}{ll}
\hline Job satisfaction & 0.888 \\
\hline Job performance & 0.805 \\
\hline
\end{tabular}

Relationships Between Job Satisfaction and Employee's Performance: For every organization, who wants to increase productivity, they need to learn all the methods through which they can improve their performance. Pushpakumari (2008) states that supporting high-performing employees needs to work hard. Employees who are satisfied motivated they are motivated. They will work hard and will work for the organization and will achieve organizational goals as well.

There is a positive relationship between job satisfaction and employees' performance in the oil plantation in Jakarta.

The data was analyzed using Statistical Package for Social Sciences (SPSS). Quantitative data was used to generate descriptive statistics, which are useful in evaluating and making relations and test hypotheses between variables of the study and these were presented. Also, a statistical test like regression analysis was used to predict value of a predictor and criteria variable. Cronbach's alpha also used for testing reliability of questionnaire. Implications in theory and practice in the fields of job satisfaction and performance. The results of research on job satisfaction and work are related to each other at a significant level. Get an understanding of the relationship between job satisfaction and work performance in the city of Jakarta. This research will help companies determine human resources related to the productivity of the company directly. This study will help top management in choosing the best factor to produce the highest satisfaction for employees, and they can get the desired level of performance from their company if the companies are satisfied. From the results of this study, showing the relationship between job satisfaction and performance in the sector needs company management to consider the two important factors to consider as the reasons behind the success of the plantation sector in Kalimantan, Indonesia. 
Table 1. Linear regression

\begin{tabular}{cccc} 
Model & $\mathrm{R}$ & R Square & Adjusted R Square \\
\hline 1 & $.558^{\mathrm{a}}$ & .311 & .298 \\
\hline
\end{tabular}

a. Predictors: (Constant), TOTAL_JOB SATISFACTION

\begin{tabular}{ccccc}
\hline & \multicolumn{4}{c}{ Partial Regression Model } \\
\hline R & R Square & $\begin{array}{c}\text { Adjusted R } \\
\text { Square }\end{array}$ & $\mathrm{p}$ \\
\hline Promotion & $.498^{\mathrm{a}}$ & .248 & .234 & .000 \\
Supervision & $.682^{\mathrm{b}}$ & .466 & .445 & .000 \\
Fringe benefit & $.690^{\mathrm{c}}$ & .476 & .445 & .000 \\
Contingent reward & $.698^{\mathrm{d}}$ & .487 & .446 & .000 \\
Operating condition & $.733^{\mathrm{e}}$ & .537 & .490 & .000 \\
Co-workers & $.735^{\mathrm{f}}$ & .541 & .483 & .000 \\
Nature of works & $.738^{\mathrm{g}}$ & .545 & .478 & .000 \\
communication & $.750^{\mathrm{h}}$ & .563 & .487 & .000 \\
& $.752^{\mathrm{i}}$ & .566 & .479 & .000 \\
\hline
\end{tabular}

\section{Conclusion}

The results of this study provide an innovative attempt at investigating an obvious link between job satisfaction and job performance; there is a positive relationship job satisfaction and job performance among employees. The value of Cronbach Alpha is $.55 \mathrm{p}=0.00$, which shows that the relationship is significant. Significant results of regression, $R 2=.311$, or 31.1 percent job satisfaction contribute toward employee performance; it was shown that there is an impact job satisfaction toward employees' performance in the oil plantation of Jakarta. Even though the results indicate that the hypotheses tested gave significant results, and it is clear that the entire directional hypotheses are true and gave positive results. If we see the differences in each aspect of job satisfaction, it can be concluded that communication factors, the nature of work, colleagues, operating conditions, contingent rewards are predictors that can be used to improve employees. From the table above, it can be seen that factor is not a good predictor of employee performance. These findings provide information that organizations should pay attention to factors that can improve performance in employees. communication between employees and task characteristics are important factors for employees to continue to perform well because these factors are very meaningful for organizations to continue to exist in global competition. Spector (1997) argues that job satisfaction illustrates how well employees are happy with their work. If employees have positive feelings towards work, employees will have a higher level of satisfaction with their work (Nisar, Riasat, \& Aslam, 2016). In line with Mahardiana and Thahir (2019) based on the findings in the assessment, to improve employee performance, it can support managers to assist the organization by paying attention to employee competencies. The attitude that must complete the tasks and responsibilities to the company must be conveyed more effectively in achieving organizational support. To increase employee motivation, managers in work units must be able to think fairly about employees. Ariani and Ratnasari (2018) also suggest that employee performance also depends on leadership, which is the motor of the organization; managers must pay more attention to employee competencies. The attitude that must complete the tasks and responsibilities to the company must be conveyed more effectively in achieving organizational support. The future researches should be conducted on larger sample size is recommended. As the sample size is smaller in this research and the number of 
females participated in this sample was very low due to which the findings might not be generalized to the whole population in employer. The most important limitation of this study, which is to be considered is that of sample size because the small sample size can arise the problem of probability of sampling error. Therefore, future researches should be conducted on larger sample size is recommended.

As the sample size is smaller in this research and the number of females participated in this sample was very low due to which the findings might not be generalized to the whole population in Punjab. The most important limitation of this research that must be considered is sample size, smaller sample size can cause problems related to generalization. Therefore, future research must be conducted on larger sample size. Because the sample size was smaller in this study and the number of women considered in this sample was very low because the findings might not be generalized for the entire population in Jakarta.

\section{References}

Ariani, M., \& Ratnasari, D. (2018). Effect of emotional intelligence against employee performance in department of labor and social. Journal of Business and Finance in Emerging Markets, 1(1), 37-50.

Campbell, J. P., McHenry, J. J., \& Wise, L. L. (1990). Modeling job performance in a population of jobs. Personnel psychology, 43(2), 313-575.

Dizgah, M. R., Chegini, M. G., \& Bisokhan, R. (2012). Relationship between job satisfaction and employee job performance in Guilan public sector. Journal of Basic and Applied Scientific Research, 2(2), 1735-1741.

Inuwa, M. (2016). Job satisfaction and employee performance: An empirical approach. The Millennium University Journal, 1(1), 90.

Khan, A. H., Nawaz, M. M., Aleem, M., \& Hamed, W. (2012). Impact of job satisfaction on employee performance: An empirical study of autonomous Medical Institutions of Pakistan. African Journal of Business Management, 6(7), 2697-2705.

Mahardiana, L., \& Thahir, H. (2019). A study of competence and motivation of employees to achieve performance in a supermarket. Review of Behavioral Aspect in Organizations and Society, 1(1), 45-56.

Mirvis, C. and Lawer (1977) Job satisfaction and job performance in bank tellers. Journal of Social Psychology (1980), 133 (4), 564-587.

Nisar, Q. A., Riasat, F., \& Aslam, S. (2016). Do intrinsic and extrinsic rewards influence the job satisfaction and job performance? Mediating role of reward system. Journal of Management Info, 11(1), 16-34.

Platis, C., Reklitis, P., \& Zimeras, S. (2015). Relation between job satisfaction and job performance in healthcare services. Procedia-Social and Behavioral Sciences, 175, 480-487.

Pushpakumari, M. D. (2008). The impact of job satisfaction on job performance: An empirical analysis. City Forum, 9 (1), 89-105.

Robbins, S. P., \& Judge, T. A. (2003). Organizational Behavior. Upper Saddle.

Sharma, M., \& Ghosh, A. (2006). Perception, of organisational climate and job satisfaction in nursing staff personnel-Influence of personality and self-efficacy. Indian Journal of Social Work, 67(3), 263-274.

Smith, D. \& Cranny, F. (1968) Job satisfaction, effort and commitment, Journal of Business Management, 123 (3), 151-164.

Spector, P. E. (1997). Job satisfaction application, assesment, causes, and consequences. California: Sage Publication, Inc. 
